\title{
Efficacy of Commercial Vaccines against H9N2 Avian Influenza Challenge in Chickens
}

\author{
Hossam A. Gado ${ }^{1,2}$, Ibrahim A. Ghanem ${ }^{1}$, Abdullah A. Selim ${ }^{3}$, Mounir M. Elsafty ${ }^{4}$, Reem A. \\ Soliman $^{4}$, Amal A.M. Eid ${ }^{1 *}$
}

${ }^{1}$ Avian and Rabbit Medicine Department, Faculty of Veterinary Medicine, Zagazig University, 44511, Zagazig, Egypt; ${ }^{2}$ Reference Laboratory for Quality Control on Poultry Production (RLQP). Animal Health Research Institute, Sharkia Branch, 44516, Zagazig, Egypt; ${ }^{3}$ Reference Laboratory for Quality Control on Poultry Production (RLQP). Animal Health Research Institute, Dokki, Giza, 12618, Egypt; ${ }^{4}$ Central laboratory for evaluation of Veterinary Biologics (CLEVB), Cairo, 11381, Egypt.

\begin{abstract}
Avian influenza (AI) is a contagious disease caused by type A influenza viruses. Despite the mild nature of H9N2 low pathogenic AIV, the virus was isolated from frequent disease outbreaks with high mortality in different parts of the world. Nine chicken flocks of different breeds and ages during 2018 were examined in Sharkia Province. The flocks were tested by real time PCR for determination of the H9N2 subtype in each sample. Likewise; they were tested for the presence of other viruses (H5, H7, NDV and IBV). Four flocks were positive for H9AIV, negative for other avian pathogens; two were positive for IBV, and three flocks were negative. Sequence analysis was carried out for HA and NA genes of two H9N2 isolates. Phylogenetic analysis revealed that the HA and NA of tested H9N2 isolates are clustered to the prototype G1-like viruses that were circulating in the Middle Eastern and forming a distinct cluster. Protection efficacy of commercial H9N2 vaccines was evaluated by two field available vaccines (vaccine $1 \mathrm{~A} /$ chicken/Egypt/ME543V/2016 and vaccine $2 \mathrm{~A} /$ chicken/Iran/Av1221/1998) through groups each (15 birds) of $\mathrm{SPF}$ one day old chicks then challenged them with a field isolate $\mathrm{A} /$ chicken/Egypt/S6/2018. Protection was evaluated by clinical signs, histopathology, weekly immune response by ELISA and HI tests and tracheal swabs were used to monitor virus shedding at 3,5 and 7 days post-challenge by qRT-PCR test. From this study, it is concluded that H9N2 vaccines are efficient to decrease and prevent $\mathrm{AI}$ shedding in specific pathogen free (SPF) chickens and give very good antibodies response against $\mathrm{H} 9 \mathrm{~N} 2$ after single vaccination with oil emulsion inactivated vaccines.
\end{abstract}

Keywords | AIV, LPAI H9N2, Sequence, SPF chickens, inactivated vaccine, Egypt

Received | April 28, 2021; Accepted | August 01, 2021; Published | December 01, 2021

"Correspondence | Amal A.M. Eid, Avian and Rabbit Medicine Department, Faculty of Veterinary Medicine, Zagazig University, 44511, Zagazig, Egypt; Email: amalaeidvet@gmail.com

Citation | Gado HA, Ghanem IA, Selim AA, Elsafty MM, Soliman RA, Eid AAM (2022). Efficacy of commercial vaccines against h9n2 avian influenza challenge in chickens. Adv. Anim. Vet. Sci. 10(1): 35-48.

DOI | http://dx.doi.org/10.17582/journal.aavs/2022/10.1.35.48

ISSN (Online) | 2307-8316; ISSN (Print) | 2309-3331

Copyright (C) 2022 Gado et al. This is an open access article distributed under the Creative Commons Attribution License, which permits unrestricted use, distribution, and reproduction in any medium, provided the original work is properly cited.

\section{INTRODUCTION}

$\mathrm{I}$ $n$ Egypt, the poultry industry is considered one of the most profitable national income (E1-Nagar and Ibrahim, 2007). Avian influenza virus (AIV) is one of the most devastating viral diseases in poultry. It has a worldwide distribution that infects many domesticated and wild birds (Swayne and Glisson, 2013).
Avian influenza viruses are divided into two pathotypes: highly pathogenic avian influenza (HPAI) viruses, which cause severe and fatal infections in chickens, and low pathogenic avian influenza (LPAI) viruses, which are generally much less virulent. LPAI viruses may contain any haemagglutinin antigen, but to date all HPAI viruses have contained either $\mathrm{H} 5$ or $\mathrm{H} 7$ (OIE, 2019). 
The H9N2 avian influenza virus (AIV) was reported to be low pathogenic in chickens (Bano et al., 2003). Still, its infection may result in significant losses in the poultry industry when complained with other pathogens (Naeem et al., 1999). In Egypt, H9N2 virus was first detected in May 2011 from bobwhite quail (El-Zoghby et al., 2012).

Recently, simultaneous detection of the three subtypes (H5N1, H5N8, and H9N2) has been described in a poultry farm in Egypt (Shehata et al., 2019). The emerged HPAI (H5N2) virus from a commercial duck farm was the first natural reassortment in Egypt resulted from a reassortant between HPAI H5N8 of clade 2.3.4.4 (group B) virus and the Egyptian LPAI (H9N2) G1-like lineage virus (Hagag et al., 2019).

Several experimental studies have reported that inactivated AI vaccines can induce antibody response, which helps protect the infected birds from mortality and egg production decline (Capua and Alexander, 2008). The monitoring of H9N2 virus shedding in an infected bird is a tool for evaluating AI vaccine effectiveness. An effective vaccine prevents clinical disease and reduces viral shedding (Subtain et al., 2011). In this study, recent LPAI H9N2 viruses were isolated and molecularly characterized from Sharkia Province. Besides, the analysis of inactivated oil emulsion Avian Influenza H9N2 vaccines efficacy in specific-pathogen-free chickens in terms of reduction of viral replication and shedding, antibody response, and histopathological examination.

\section{MATERIALS AND METHODS}

\section{SAMPLING AND SAMPLE PROCESSING}

The current investigation was done to detect and isolate field H9 subtype AI virus to be used in challenge studies in nine suspected flocks (broilers, balady, and layers; 3/ each). Eighty tracheal and cloacal swabs, besides seven respiratory tissues, were collected for this purpose at Sharkia Province during 2018. The history of the investigated flocks (breed, age, vaccination, and flock capacity) was illustrated (Supplementary Table S1). The samples were kept at $-80^{\circ} \mathrm{C}$ until examination. Tissue samples were pooled (each pool consists of trachea and lungs from three birds), then each was homogenized in an adequate volume $(1: 10 \mathrm{w} / \mathrm{v})$ of sterile phosphate-buffered saline. The tissue homogenates were centrifuged at $1000 \times \mathrm{g}$ for $10 \mathrm{~min}$. Penicillinstreptomycin mixture (Lonza Group AG, Walkersville, MD) was added to each supernatant (1000 IU penicillin and $1000 \mu \mathrm{g}$ streptomycin per milliliter). Tracheal swabs were pooled (5/each) in $2 \mathrm{ml}$ of PBS solution containing antibiotics, followed by centrifugation at $1000 \times \mathrm{g}$ for 10 min, and the supernatants were collected into cryotubes (OIE manual, 2015).
Avian influenza H9 detection using Real-time RT-PCR

All collected swabs and tissue homogenates were subjected to Real-time RT-PCR. Samples tested for Matrix and H9 genes and other suspected co-infections (H5, H7, IBV, and NDV). RNA was extracted from samples using QIAamp Viral RNA Mini Kit (Qiagen, Valencia, Calif., USA). Cat. No.52904. The procedure was done according to the company's work instructions. The amplification process was performed using Quantitect RT-PCR Kit reaction buffer (Qiagen. 204443- USA). Stratagene MX3005P real-time PCR machine (Stratagene, USA) was used. Primers and probes were supplied from Metabion (Germany) (Table 1). The reaction mix volumes for each reaction of the Matrix, $\mathrm{H} 9, \mathrm{H} 5$ and $\mathrm{H} 7$ genes of avian influenza viruses, IBV and NDV, were 5ul RNA template; $0.25 \mathrm{ul}$ for RTenzyme $12.5 \mathrm{ul}$ for RT-PCR buffer; $0.5 \mathrm{ul}$ of each forward and reverse primers; $0.125 \mathrm{ul}$ for probe, and $6.125 \mathrm{uL}$ of RNase-free water. Thermal cycling RT-PCR conditions included a reverse transcription at $50^{\circ} \mathrm{C}$ for $30 \mathrm{~min}$, then an inactivation of reverse transcription enzyme and initial denaturation at $95^{\circ} \mathrm{C}$ for $15 \mathrm{~min}$, followed by 40 cycles at (Table 1).

GeNETIC CHARACTERIZATION OF HA AND NA GENES Amplification of HA and NA genes for two selected positive samples (S2 and S6): it was implemented by one-step RT-PCR using Qiagen kit (QIAGEN, Hilden, Germany) with specific primers in (Table 2), The RT-PCR cycling as follows: one cycle at $50^{\circ} \mathrm{C}$ for $30 \mathrm{~min}$, one cycle at $95^{\circ} \mathrm{C}$ for $15 \mathrm{~min}$ and 40 cycles of $94^{\circ} \mathrm{C}$ for $45 \mathrm{Sec}, 56^{\circ} \mathrm{C}$ for $45 \mathrm{Sec}$ and $72^{\circ} \mathrm{C}$ for $2 \mathrm{~min}$., a final extension at $72^{\circ} \mathrm{C}$ for $10 \mathrm{~min}$. in thermocycler $2720 \mathrm{ABI}$.

\section{Sequencing for HA And NA genes}

Both HA and NA gene sequencing was done by using Big dye Terminator V3.1 cycle sequencing kit. (PerkinElmer, Foster City, CA). The cycling protocol for sequence reactions is: one cycle at $96^{\circ} \mathrm{C}$ for one min, 25 Cycles repeated at $96^{\circ} \mathrm{C}$ for $10 \mathrm{Sec}, 50^{\circ} \mathrm{C}$ for $5 \mathrm{Sec}$. and $60^{\circ} \mathrm{C}$ for $2 \mathrm{~min}$. The sequencing reactions were purified using a spin column Centrisep kit (Applied Biosystems, USA), then loaded in a sequencer plate of ABI (Applied Biosystems 3130 genetic analyzers, USA).

Nucleotide and amino acid identities were determined using the Meg Align module of Lasergene DNA Star software (Madison, WI). The nucleotide sequences were submitted to GenBank with accession numbers MT463345, MT463385, MT463346, MT463386, respectively. Nucleotide sequences were aligned, and phylogenetic analysis was performed using the neighborjoining method in the Molecular Evolutionary Genetics Analysis (MEGA7) at 1000 Bootstrap (Kumar et al., 2016). 
Table 1: Primers, probes and conditions applied in real time PCR for detection of AI, ND and IB viruses and Mycoplasma species supplied from Metabion (Germany).

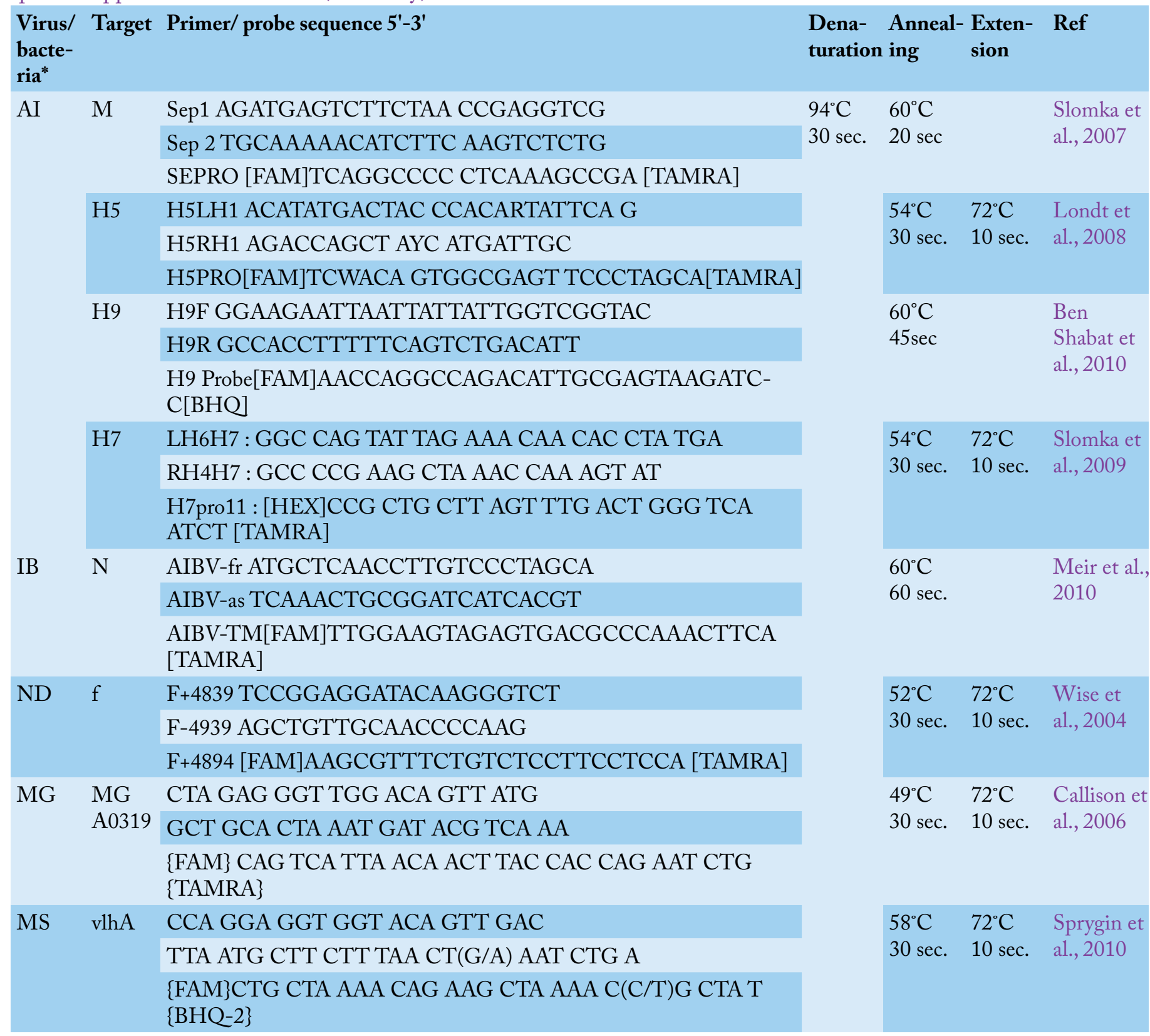

Avian Influenza = AI, Newcastle disease virus= NDV, infectious bronchitis virus= IBV, Mycoplasma Gallisepticum $=$ MG and Mycoplasma Synoviae $=$ MS.*

Table 2: Primers used in Reverse Transcriptase-PCR for sequencing of HA and NA genes of AIV H9 subtype.

\begin{tabular}{|c|c|c|c|}
\hline Prime ID & Gene & Nucleotide Sequence 5'-3' & Reference \\
\hline F1-6 & \multirow[t]{4}{*}{ H9 } & TAG CAA AAG CAG GGG AAT TTC TT (1-23) & \multirow[t]{4}{*}{ Adel et al., 2016} \\
\hline H9- R940 & & GCC ACC TTT TTC AGT CTG ACA TT (898-920) & \\
\hline H9-For & & GGA AGA ATT AAT TAT TAT TGG TCG GTA C (738-765) & \\
\hline HT7R & & $\begin{array}{l}\text { TAA TAC GAC TCA CTA TAA GTA CAA ACA AGG GTG } \\
(1731-1763)(1731-1763)\end{array}$ & \\
\hline N2-F1 & \multirow[t]{4}{*}{$\mathrm{N} 2$} & ATG AAT CCA AAT CAA AGG ATA A & \multirow{4}{*}{$\begin{array}{l}\text { Designed by RLQP- } \\
\text { Manufactured by (Metabion- } \\
\text { Germany) RLQP }\end{array}$} \\
\hline N2-R950 & & CGC CAA CAA GTC CTG AGC ACA CAT & \\
\hline N2-F630 & & CAT GGG ATG CTT ACC GAC AGT ATT & \\
\hline N2-R1410 & & GAA AGC TTA TAT AGG CAT GAA AT & \\
\hline
\end{tabular}


Table 3: Experimental design for Evaluation of H9N2 inactivated oil emulsion commercial vaccines in SPF chickens.

\begin{tabular}{|c|c|c|c|c|c|}
\hline \multirow{2}{*}{$\begin{array}{l}\text { Group } \\
\text { No. }\end{array}$} & \multirow{2}{*}{$\begin{array}{l}\text { No. of } \\
\text { birds }\end{array}$} & \multicolumn{3}{|l|}{ Vaccine regime* } & \multirow[t]{2}{*}{ Challenge at 28-day of age } \\
\hline & & $\begin{array}{l}\text { vaccine type } \\
\text { inactivated vaccine }\end{array}$ & Age/days & Dose/bird & \\
\hline G1 & 15 & $\begin{array}{l}\text { vaccine } 1 \mathrm{~A} / \text { chicken/Egypt/ME543V/2016 } \\
\text { batch No.1908080101 } 350 \mathrm{HA} \text { unit }\end{array}$ & 7 day & $0.5 \mathrm{ml} \mathrm{S} / \mathrm{C}$ & --- \\
\hline G2 & 15 & $\begin{array}{l}\text { vaccine } 2 \mathrm{~A} / \text { chicken/Iran/Av1221/1998 } \\
\text { batch No. B10335 } \geq 10 \text { HI.U }\end{array}$ & 7 day & $0.3 \mathrm{ml} \mathrm{S} / \mathrm{C}$ & --- \\
\hline G3 & 15 & $\begin{array}{l}\text { vaccine } 1 \mathrm{~A} / \text { chicken/Egypt/ME543V/2016 } \\
\text { batch No.1908080101 } \\
350 \text { HA unit }\end{array}$ & 7 day & $0.5 \mathrm{ml} \mathrm{S} / \mathrm{C}$ & ++ $1 \times 10^{6} \mathrm{EID}_{50}$ per $0.1 \mathrm{ml}$ per bird. \\
\hline G4 & 15 & $\begin{array}{l}\text { vaccine } 2 \mathrm{~A} / \text { chicken/Iran/Av1221/1998 } \\
\text { batch No. B10335 } \geq 10 \text { HI.U }\end{array}$ & 7 day & $0.3 \mathrm{ml} \mathrm{S} / \mathrm{C}$ & $++1 \times 10^{6} \mathrm{EID}_{50}$ per $0.1 \mathrm{ml}$ per bird \\
\hline G5 & 15 & --- & --- & --- & $++1 \times 10^{6} \mathrm{EID}_{50}$ per $0.1 \mathrm{ml}$ per bird \\
\hline G6 & 15 & --- & --- & --- & --- \\
\hline
\end{tabular}

*Assessment of protection was done by virus shedding monitoring at 3, 5,7 days post challenge by qRT-PCR, serological by ELISA and $\mathrm{HI}$ tests and histopathological findings.

\section{Chicken EMbryo inOCULATION}

The two selected viruses (S2 and S6) were propagated on 10 days old SPF embryonated chicken eggs (ECE) through intra-allantoic inoculation, and then incubated at $37^{\circ} \mathrm{C}$ for 3-5 days. The SPF-ECEs were obtained from the National SPF egg project, Kom Oshim, EL-Fayoum Province. The allantoic fluids were harvested from the inoculated embryos and tested for virus hemagglutination properties (OIE Manual, 2015). The titration of each virus was calculated (Reed and Muench, 1938) to determine the $50 \%$ embryo infectious dose titer $\left(\mathrm{EID}_{50}\right)$.

\section{Purity of H9 AIV viruses}

Samples were subjected to test the purification after virus isolation and titration to make sure that they were negative for other common avian pathogens, such as Newcastle disease virus (NDV), infectious bronchitis virus (IBV), AIV (H5, H7), Mycoplasma gallisepticum (MG) and Mycoplasma synoviae (MS) (Table 1).

\section{Challenge virus}

The used H9N2 LPAIV Egyptian isolate (A/chicken/ Egypt/S6/2018) was selected based on its purity, low CT $(\mathrm{CT}=11)$. The virus was diluted to adjust the amount of inoculum to $1 \times 10^{6} \mathrm{EID}_{50}$ per $100 \mu \mathrm{l}$ per bird).

\section{IN VIVO EVALUATION OF H9 VACCINES}

One hundred one-day-old chicks were kept in biosafety isolators previously cleaned and disinfected in Central Lab for Evaluation of Veterinary Biologics (CLEVB); feed and water were supplied ad libitum. The experimental design for evaluation of the effectiveness of $\mathrm{H} 9 \mathrm{~N} 2$ avian influenza inactivated vaccines was shown in (Table 3).

\section{VACCINE EFFICACY EVALUATION}

Daily observation and recording of clinical findings, virus shedding, serological and histopathological findings were carried out for the vaccine evaluation.

\section{Clinical and PM examination}

The chickens were observed daily for signs of disease and mortality for 14 days post-challenge. The PM examination was done for the euthanized birds for histopathology as well.

\section{VIRUS SHEDDING}

A total of 90 tracheal swabs were collected (5/each group) on viral transporting media; consisting of $10 \%$ glycerol, 200 $\mathrm{U}$ of penicillin per $\mathrm{mL}, 200 \mathrm{mg}$ of streptomycin per $\mathrm{mL}$, $250 \mathrm{mg}$ of gentamicin per $\mathrm{mL}$, and $50 \mathrm{U}$ of nystatin per $\mathrm{mL}$. The collection was at the $3^{\text {rd }}, 5^{\text {th }}$ and $7^{\text {th }}$ days post -challenge. The samples were kept at $-80^{\circ} \mathrm{C}$ till being examined by qRT-PCR for detection and titration of shedders of AIV H9N2 challenge virus. A Standard curve was calculated using $\mathrm{A} /$ chicken/Egypt/S6/2018 by serial dilutions of the virus from $10-1$ to $10-6$. Since Ct. is defined as the point at which the curve crosses the horizontal threshold line. The virus $\log 10$ titers of was plotted against the $\mathrm{Ct}$ value, and the best fit line was constructed. AIV-H9N2 quantity in unknown samples was derived by plotting the CT of an unknown against the standard curve and was expressed in $\log 10 \mathrm{EID} 50 / \mathrm{mL}$ equivalents. RNA extraction from swabs was carried out by QIAamp viral RNA extraction kit (Qiagen, Valencia, Calif., USA) as per the manufacturer's protocol.

\section{SEROLOGY}

Blood samples were collected separately from 5 birds / group at the $1^{\text {st }}, 7,14,21,28,35$ and 42 days of age and sera were separated and kept in sterile tubes at $-20^{\circ} \mathrm{C}$.

\section{ENZYME-LINKED IMMUNOSORBENT ASSAY}

To monitor the immune response after vaccination the 
authors used the commercially available H9 AIV antibody test kit (ID-screen Influenza H9 indirect, Grabels, France) lot number G11. The kit was used according to the manufacturer's instructions. Samples were tested in duplicates. Controls; antigen, known positive and negative sera were included. Optical density values were read at 450 $\mathrm{nm}$ using an ELISA microplate reader (Sunrise, Tecan, Grodig, Austria).

\section{HeMagglutination inhibition (HI) ASSAY}

The HI test was carried out by using $4 \mathrm{HA}$ units of avian influenza using two antigens (reference imported antigen VLDIA113-INFH9, supplied from GD lab Lot No. 19660-040419 and Local antigen provided kindly from ME-VAC company batch No. RD200101AG), (OIE Manual, 2015).

\section{Histopathological EXAMinATION}

Three chickens from each group were humanly euthanized and subjected to necropsy at the 5th-day post-challenge. Trachea, lungs, bursa, cecal tonsils, thymus, and kidney were collected and kept in 10\% buffered formalin for 24 hours (Suvarna et al., 2018).

\section{STATISTICAL ANALYSIS}

The obtained data were subjected to one-way analysis of variance using SPSS (version 22, Armonk, NY, USA). Differences within means of treatments were tested at $p$ $<0.5$.

\section{RESULTS AND DISCUSSION}

\section{Clinical And PM findings}

The naturally affected broiler flocks revealed respiratory signs: sneezing, swelling of periorbital tissues with conjunctivitis, nasal and ocular discharges. Whitish diarrhea also was noticed. The postmortem findings of the examined broilers revealed tracheitis, congestion of lungs, and air-sacculitis. Swollen Kidney was also detected. Mortality rates ranged from $3 \%$ to $5 \%$ in examined broiler flocks. Drop-in egg production ranged from 25\% to 30\% in affected layer flocks with thin-shelled, rough, and misshapen eggs.

\section{Molecular Detection of AIV, IBV AND NDV}

Real time RT-PCR was positive in four samples for Matrix and $\mathrm{H} 9$ genes and negative for other viruses. IBV was detected in two samples. Neither of $\mathrm{H} 5, \mathrm{H} 7$ subtypes, and NDV was detected (Table 4).

\section{Surface glycoproteins HA and NA Amino acid} IDENTITIES

Regarding sequencing of $\mathrm{HA}$ and NA genes in two selected H9 subtype isolates, the HA gene amino acid homology of the two H9 isolates was $97.2 \%$ with each other. The HA gene amino acid identities of $\mathrm{A} /$ chicken/ Egypt/S2/2018 and A/chicken/Egypt/S6/2018 with other contemporary Egyptian isolates (2012-2019) were 94-98.6 95.6-98.8\%, respectively. The HA gene of the current two isolates shared amino acid homology of 88.8 and $90 \%$, respectively, with the prototype HK-G1. In comparison with the four $\mathrm{H} 9 \mathrm{~N} 2$ vaccine strains used in commercial vaccines in Egypt (A/chicken/Saudi Arabia/ CP7/1998, A/ chicken/Iran/av1221/1998, A chicken Egypt ME543V 2016 and A chicken UAE AG53799), ranges of deduced amino acid identities were 91.4 to $92.6 \%, 91.2$ to $92.3 \%, 97.4$ to $99.3 \%$ and, 91.9 to $93 \%$ respectively. Our isolates were closely related to the Israeli viruses, with a high identity percentage ranged from $94.4-96.7 \%$

Table 4: Molecular detection of avian influenza viruses and other suspected coinfections (IBV and NDV) by realtime PCR.

\begin{tabular}{lllllllllll} 
Sample & \multicolumn{7}{c}{ Sample } & \multicolumn{8}{c}{ Results } \\
No. & ID & M & CT & H5 & H7 & H9 & CT & ND & IB & CT \\
1 & S1 & + & 26 & - & - & + & 27 & - & - & $>40$ \\
2 & S2 & + & 24 & - & - & + & 25 & - & - & $>40$ \\
3 & S3 & - & $>40$ & - & - & - & $>40$ & - & - & $>40$ \\
4 & S4 & - & $>40$ & - & - & - & $>40$ & - & + & 16 \\
5 & S5 & - & $>40$ & - & - & - & $>40$ & - & + & 15 \\
6 & S6 & + & 22 & - & - & + & 23 & - & - & $>40$ \\
7 & S7 & - & $>40$ & - & - & - & $>40$ & - & - & $>40$ \\
8 & S8 & - & $>40$ & - & - & - & $>40$ & - & - & $>40$ \\
9 & S9 & + & 27 & - & - & + & 28 & - & - & $>40$
\end{tabular}

$\mathrm{CT}>40$ is considered negative result; M, Matrix gene; Newcastle disease virus, NDV; infectious bronchitis virus, IBV.

However, The NA gene amino acid homology was 97.9\% between two of our isolates. The percentages of NA gene amino acid identities of $\mathrm{A} /$ chicken/Egypt/S2/2018 and $\mathrm{A} /$ chicken/Egypt/S6/2018 with Egyptian isolates (20122016) were $94.5-97.6$ and $94.8-97.4 \%$, respectively. The NA gene shared amino acid homology of 90.5 and $90.8 \%$ with the HK-G1 prototype. Compared with the H9N2 vaccine strains used in commercial vaccines in Egypt (A/ chicken/Saudi Arabia/CP7/1998 and A/ chicken/Iran/ av1221/1998), ranges of amino acid identities were $92.2 \%$ and 91.5, respectively (Table 5).

\section{Phylogenetic analysis}

Phylogenetic analysis of the HA, NA genes showed that our Egyptian isolates of H9N2 AIV were grouped in the Quail/HK/G1/97 lineages, similar to the viruses circulating in the Middle East close phylogeny to the Israeli viruses (Figure 1). 


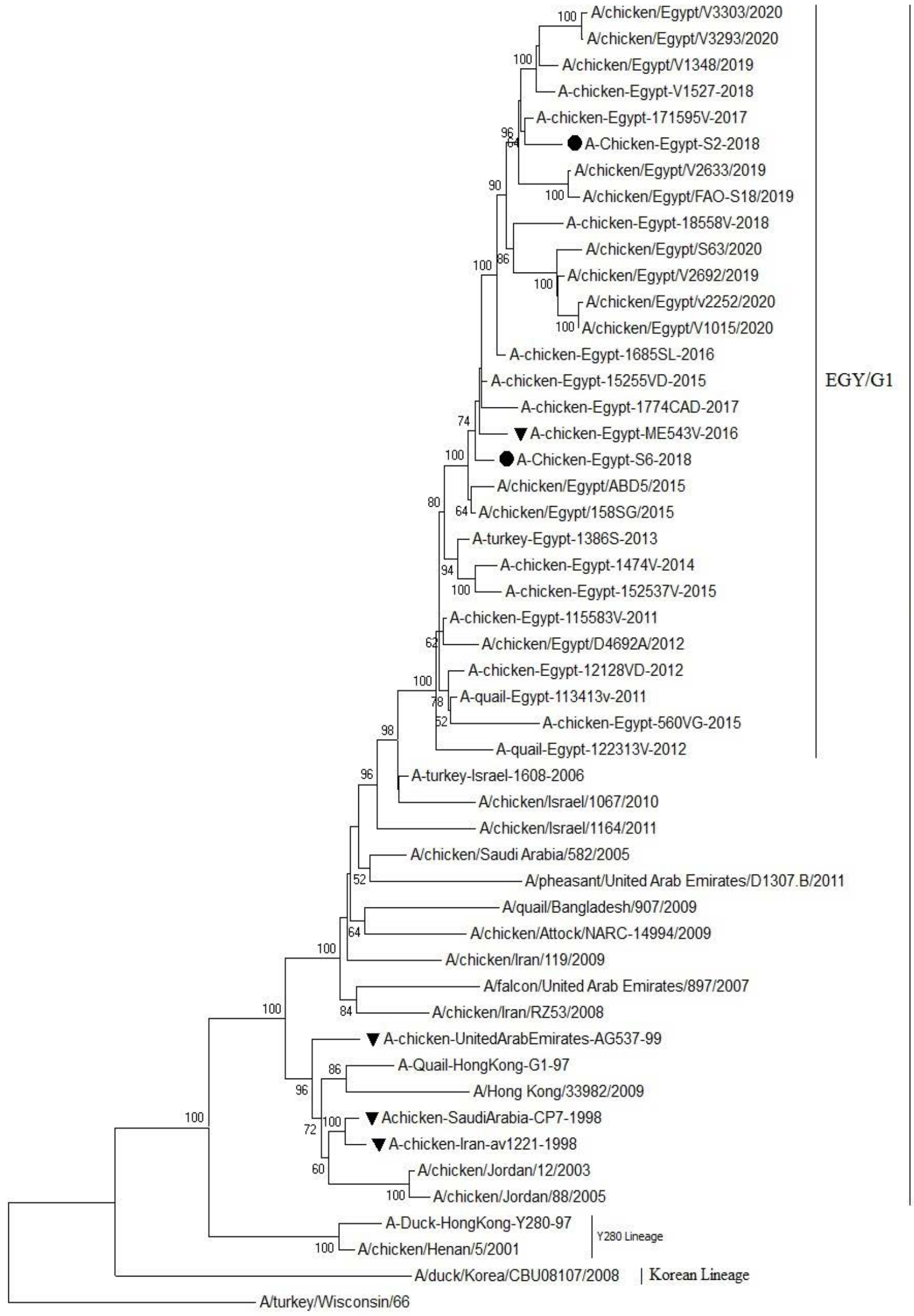

G1 Lineage

A

0.02

January 2022 | Volume 10 | Issue 1 | Page 40 


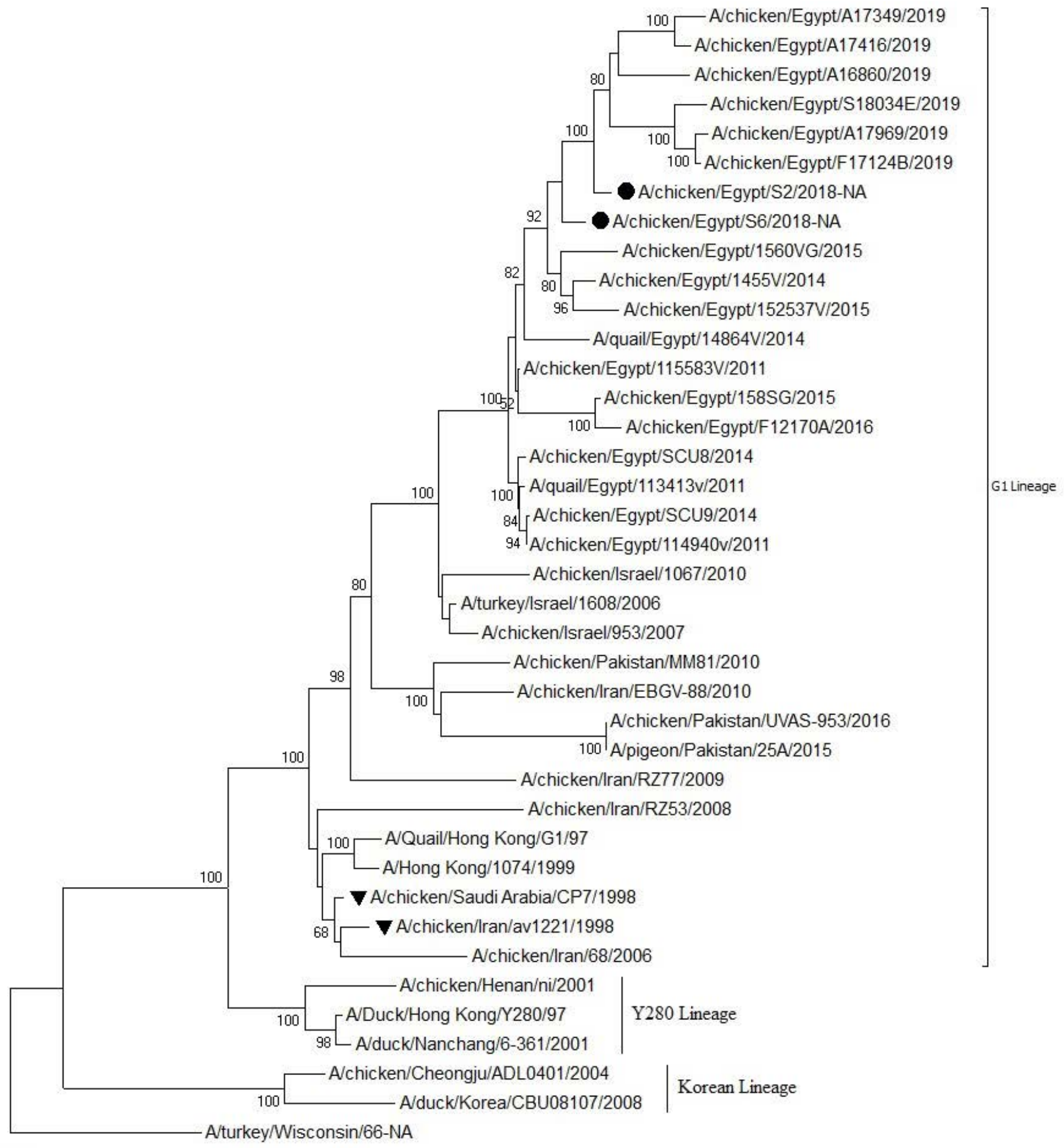

\section{B $\lcm{0.02}$}

Figure 1: Phylogenetic analysis of H9 and N2 genes nucleotide sequences of AIV (S2andS6) isolates from Sharkia Province, Egypt and other sequences available in GenBank. (A) The tree was constructed via multiple alignments of 1465 bp nucleotide sequence of HA gene. (B) The tree was constructed via multiple alignments of $1265 \mathrm{bp}$ of NA gene, using the neighbor-joining method and the Kimura-2-parameter models in MEGA7. Strain A/Turkey/Wisconsin/1966 was used as the root of the tree at 1000 bootstrap replicates. Isolates in this study are marked with solid circle. Vaccine seeds are marked triangle.

\section{VIRUS ISOLATION}

The $\mathrm{H} 9$ virus isolation trials in SPF ECE revealed survival of the embryos within (2-4) days after inoculation. The
HA titer for the harvested allantoic fluid was (128 and 512) for S2 and S6, respectively. 
Table 5: Percent amino acid identity comparison between our study isolates with other viruses and vaccinal seeds.

\begin{tabular}{|c|c|c|c|c|}
\hline \multirow[t]{2}{*}{ Viruses } & \multicolumn{2}{|c|}{$\begin{array}{l}\text { A/chicken/ } \\
\text { Egypt/ } \\
\text { S2/2018 }\end{array}$} & \multicolumn{2}{|c|}{$\begin{array}{l}\text { A/chicken/ } \\
\text { Egypt/ } \\
\text { S6/2018 }\end{array}$} \\
\hline & HA & NA & HA & NA \\
\hline Each other & $97.2 \%$ & $97.9 \%$ & ---- & ---- \\
\hline A-Quail-HK-G1-97 & $88.8 \%$ & $90.5 \%$ & $90 \%$ & $90.8 \%$ \\
\hline A/quail/Egypt/113413v/2011 & $96.5 \%$ & $96.9 \%$ & $98.1 \%$ & $97.4 \%$ \\
\hline A-Duck-HongKong-Y280-97 & $88.6 \%$ & $89.8 \%$ & $89.3 \%$ & $89.8 \%$ \\
\hline A-chicken-Egypt-ME543V-2016 & $97.4 \%$ & nd & $99.3 \%$ & nd \\
\hline Achicken-SaudiArabia-CP7-1998 & $91.4 \%$ & $92.2 \%$ & $92.6 \%$ & $92.2 \%$ \\
\hline A-chicken-Iran-av1221-1998 & $91.2 \%$ & $91.5 \%$ & $92.3 \%$ & $91.5 \%$ \\
\hline A-chicken-UAE-AG537-99 & $91.9 \%$ & nd & $93 \%$ & $\mathrm{Nd}$ \\
\hline A/quail/Egypt/122313v/2012 & $94 \%$ & nd & $95.6 \%$ & $\mathrm{Nd}$ \\
\hline A/chicken/Egypt/D5490B/2012 & nd & $97.6 \%$ & nd & $97.4 \%$ \\
\hline A/turkey/Egypt/1386s/2013 & $96.5 \%$ & nd & $98.4 \%$ & nd \\
\hline A/chicken/Egypt/F7297B/2013 & nd & $96.7 \%$ & nd & $97.2 \%$ \\
\hline A/chicken/Egypt/1474v/2014 & $95.1 \%$ & nd & $97 \%$ & nd \\
\hline A/Quail/Egypt/14864v/2014 & nd & $94.5 \%$ & nd & $96 \%$ \\
\hline A/chicken/Egypt/152537v/2015 & $96.5 \%$ & nd & $98.4 \%$ & nd \\
\hline A/chicken/Egypt/1560VG/2015 & nd & $97.2 \%$ & nd & $96.4 \%$ \\
\hline A/chicken/Egypt/1685SL/2016 & $97.4 \%$ & nd & $98.8 \%$ & nd \\
\hline A/chicken/Egypt/F12168B/2016 & nd & $94.3 \%$ & nd & $94.8 \%$ \\
\hline A/chicken/Egypt/17159v/2017 & $98.6 \%$ & nd & $97.7 \%$ & $\mathrm{Nd}$ \\
\hline A/chicken/Egypt/V1527/2018 & $98.6 \%$ & nd & $97.7 \%$ & $\mathrm{Nd}$ \\
\hline A/chicken/Egypt/V2692/2019 & $97.2 \%$ & nd & $97.7 \%$ & $\mathrm{Nd}$ \\
\hline A-Turkey-israel-1608-2006 & $95.3 \%$ & $96.4 \%$ & $96.7 \%$ & $96.9 \%$ \\
\hline A-Chicken-israel1067-2010 & $94.4 \%$ & nd & $96.3 \%$ & nd \\
\hline
\end{tabular}

\section{Purity OF H9 AIV isolates}

Real time PCR of isolates 2 and 6 after isolation in SPF ECE were positive for H9 AIV only with CT $=18$ and 11, respectively and negative for ( $\mathrm{H} 5$ and $\mathrm{H} 7$ subtypes, IBV, MG, MS and ND).

\section{VirUs TITRATION}

The pure strain (A/chicken/Egypt/S6/2018) was titrated in SPF ECE and revealed 10 9.5/ $100 \mu \mathrm{L} \mathrm{EID}_{50}$.

\section{Challenge STUdy Findings}

\section{Clinical signs}

No mortalities were recorded in all groups along the period of experimentation. All birds in the five groups (G1, G2, G3, G4 and G6) did not develop any signs of clinical illness all over the 14 days of monitoring on a daily basis. The G5 (positive control group) birds developed clinical illness starting at the $3^{\text {rd }}$ day post-challenge, which completely stopped at the $7^{\text {th }}$-day post-challenge. The commonly observed clinical manifestations were; reduction in the feed consumption rate, general depression, and diarrhea.
Gross LESIONS

There were no detectable gross lesions in all organs of the chickens for different groups except G5 two birds showed lesions of mild pneumonia, congestion in the small intestine, and mildly swollen kidneys.

\section{Tracheal SHEDDING}

There was no tracheal shedding in G1, G2, G4, and G6 throughout the experiment. One bird only showed tracheal shedding in $\mathrm{G} 3$ at the $3^{\text {rd }}$ day post-infection (DPI) $(1 / 5)$ with titer $\left(1.511 \times 10^{5}\right.$. All challenged birds in G5 showed shedding H9N2 AIV at the $3^{\text {rd }}$ DPI (5/5) with amount $\left(2.657 \times 10^{7}, 4.474 \times 10^{7}, 6.049 \times 10^{7}, 1.135\right.$ x $10^{7}$ and $1.514 \times 10^{7}$, respectively). At the $5^{\text {th }}$ day postchallenge, three birds in G5 were positive (3/5) with titer $\left(1.184 \times 10^{8}, 6.658 \times 10^{7}\right.$, and $6.515 \times 10^{6}$, respectively). The shedding in infected non vaccinated birds stopped at $7^{\text {th }}$ day post-infection (DPI) (Table 6).

\section{SERological RESPONSE}

The mean antibody titers detected by $\mathrm{HI}$ for $\mathrm{H} 9$ AIV in different groups of SPF chickens are represented in Figure 2. The antibodies were detected by ELISA in 50\% and $80 \%$ of vaccinated birds at two weeks post-vaccination but increased to $100 \%$ at the $3^{\text {rd }}$ week P (Table 7 ).

\section{Histopathological EXAMination}

Histopathological findings revealed mild desquamation of tracheal epithelium, low degree of interstitial pneumonia and interstitial inflammatory cells infiltrations in the kidneys of the positive control group (G5) as shown in (Figure 3).

Avian influenza (AI) is a respiratory disease in poultrycaused by influenza $A$ viruses of the family Orthomyxoviridae. Several virus subtypes are classified according to the two major surface glycoprotein: Hemagglutinin $(\mathrm{H})$ and neuraminidase (N) (Luczo et al., 2015).

In the Middle East, H9N2 AIV has been reported for several years, indicating additional risk to poultry production. It is a significant concern the spread of $\mathrm{H} 9 \mathrm{~N} 2$ in Egypt can negatively affect poultry health overall and increase the risk of $\mathrm{H} 5 \mathrm{~N} 1 \mathrm{andH} 5 \mathrm{~N} 8 \mathrm{HPAI}$ infections (Hegazy et al., 2019).

The current study throws light on the isolation and molecular characterization of recent circulating LPAI H9N2 at Sharkia Province for more accurate identification. As well as to evaluate the commercial in SPF chickens through viral replication and shedding by qRT-PCR, serological response using ELISA and HI tests, and clinical and histopathological examination. 

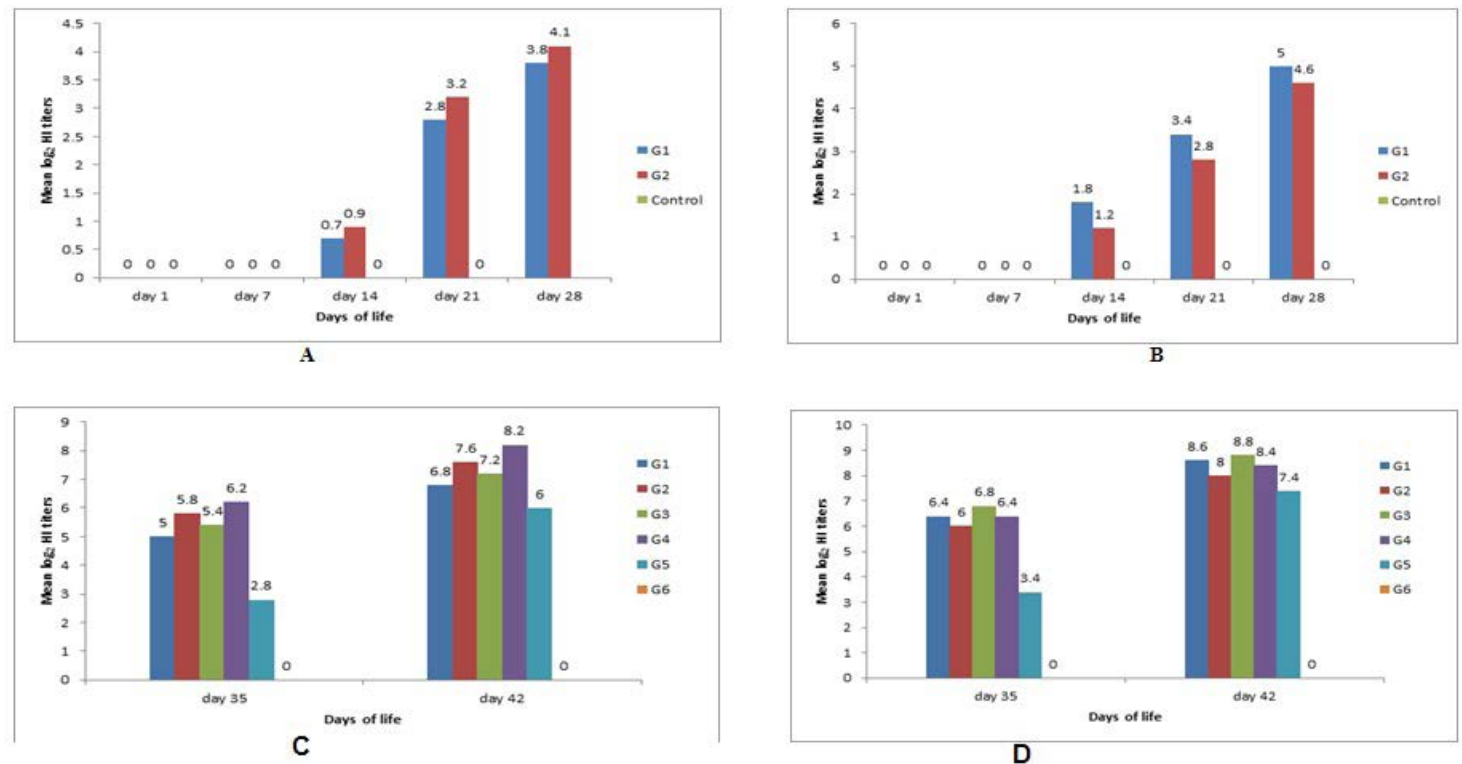

Figure 2: Geometric mean $\log ^{2}$ of $\mathrm{HI}$ titers in experimental SPF chickens using two antigens, G1: vaccine 1 non challenged, G2: vaccine 2 non challenged, G3: vaccine 1 challenged, G4: vaccine 2 challenged, G5: challenged non vaccinated (Pos control), G6: non treated (Neg control). (A) HI test results using imported antigen: representing vaccine 2 seed virus from day 1 to day 28 before challenge, (B) HI test results using local antigen: Local antigen similar to vaccine 1 seed virus from day 1 to day 28 before challenge, (C) HI test results using imported antigen: representing vaccine 2 seed virus day 35 ( $1^{\text {st }}$ week post challenge $)$ and day 42 ( $2^{\text {nd }}$ week post challenge $)$, (D)HI test results using local antigen: Local antigen similar to vaccine 1 seed virus day 35 ( $1^{\text {st }}$ week post challenge $)$ and day 42 ( $2^{\text {nd }}$ week post challenge).
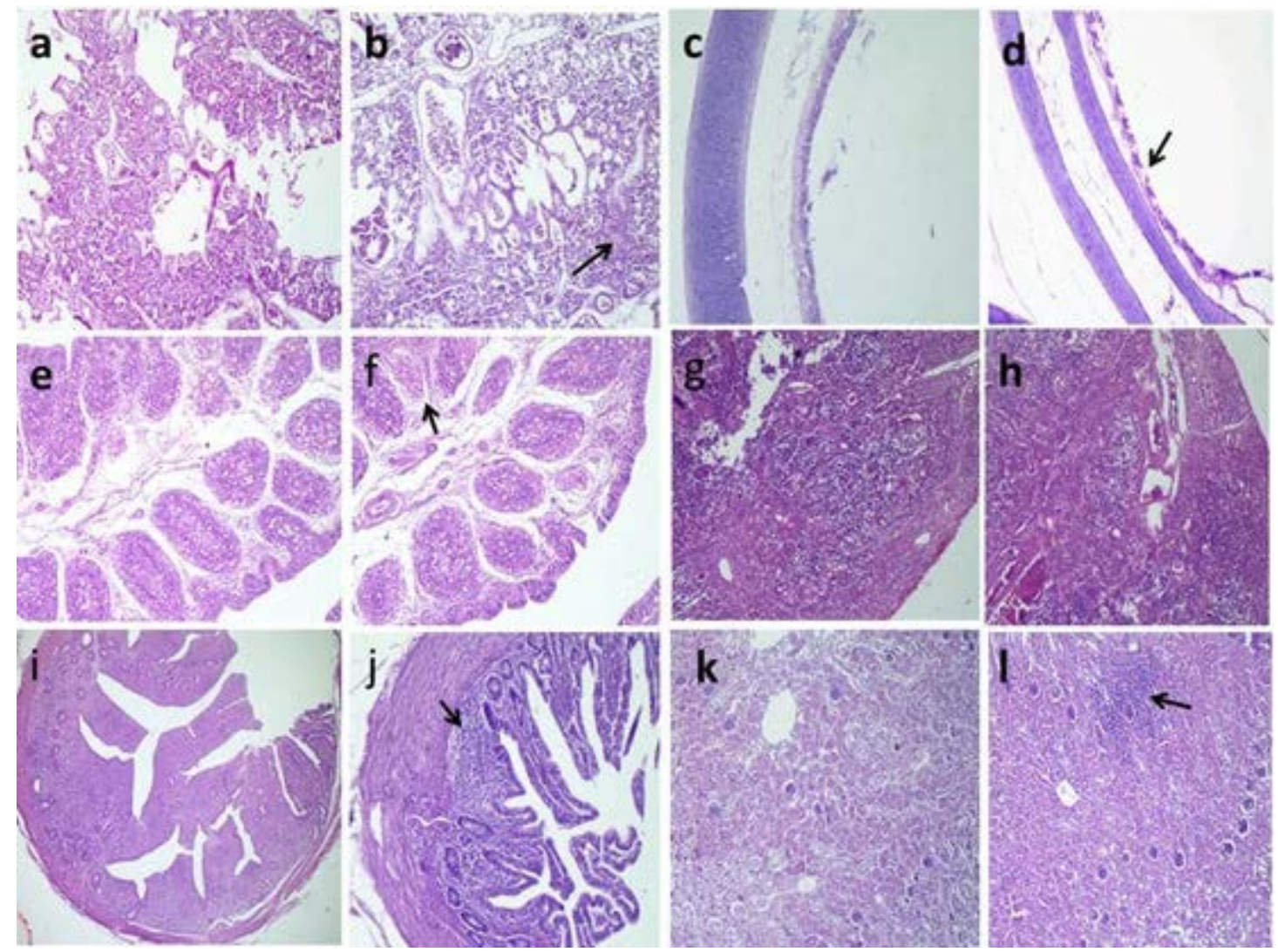

Figure 3: Histopathologic findings of chickens 5 days after challenge with AIV H9N2. a, Normal pulmonary tissues in G6; b, Interstitial pneumonia (arrow) in G5; c,Normal tracheal tissues in G6; d, Mild desquamated tracheal epithelium (arrow) in G5; e, Normal lymphoid follicles in G6; f, Necrotic some lymphoid follicles (arrow) in G5; g, Normal cortical and medullary lymphoid population in G6; h, congested blood vessels with thickening of septae in G5; i, normal lymphoid aggregations in G6; j, partial depletion (arrow) in G5; k, normal renal glomerular and tubular structure in G6; 1, interstitial inflammatory cells infiltrations (arrow) in G5 $\mathrm{H}$ and $\mathrm{E}$ stain. 
Table 6: Mean titer* of virus shedding and number of shedder in vaccinated and non-vaccinated challenged with H9N2 virus in SPF chickens.

\begin{tabular}{|c|c|c|c|c|c|c|c|}
\hline \multirow{3}{*}{$\begin{array}{l}\text { Group } \\
\text { No }\end{array}$} & \multirow[t]{3}{*}{ Group treatment } & \multicolumn{6}{|c|}{ H9N2 virus shedding in tracheal swabs post challenge } \\
\hline & & \multicolumn{2}{|c|}{$3^{\text {rd }}$ day post challenge } & \multicolumn{2}{|c|}{$5^{\text {th }}$ day post challenge } & \multicolumn{2}{|c|}{$7^{\text {th }}$ day post challenge } \\
\hline & & $\begin{array}{l}\text { Titer } \\
(\text { mean } \pm S D)\end{array}$ & $\begin{array}{l}\text { No. shedders } \\
\text { (pos/total) }\end{array}$ & $\begin{array}{l}\text { Titer } \\
(\text { mean } \pm S D)\end{array}$ & $\begin{array}{l}\text { No. shedders } \\
\text { (pos/total) }\end{array}$ & $\begin{array}{l}\text { Titer } \\
(\text { mean } \pm S D)\end{array}$ & $\begin{array}{l}\text { No. shedders } \\
\text { (pos/total) }\end{array}$ \\
\hline G1 & $\begin{array}{l}\text { Vaccinated non challenged } \\
\text { (Vaccine } 1)\end{array}$ & 0 & $0 / 5$ & 0 & $0 / 5$ & 0 & $0 / 5$ \\
\hline G2 & $\begin{array}{l}\text { Vaccinated non challenged } \\
\text { (Vaccine 2) }\end{array}$ & 0 & $0 / 5$ & 0 & $0 / 5$ & 0 & $0 / 5$ \\
\hline G3 & $\begin{array}{l}\text { Vaccinated challenged } \\
\text { (Vaccine 1) }\end{array}$ & $\begin{array}{l}0.230 \\
x 10^{5} \pm 0.06\end{array}$ & $1 / 5$ & 0 & $0 / 5$ & 0 & $0 / 5$ \\
\hline G4 & $\begin{array}{l}\text { Vaccinated challenged } \\
\text { (Vaccine 2) }\end{array}$ & 0 & $0 / 5$ & 0 & $0 / 5$ & 0 & $0 / 5$ \\
\hline G5 & Non Vaccinated challenged & $\begin{array}{l}3.165 \mathrm{x} \\
10^{7} \pm 0.26\end{array}$ & $5 / 5$ & $\begin{array}{l}3.829 \mathrm{x} \\
10^{7} \pm 0.5\end{array}$ & $3 / 5$ & 0 & $0 / 5$ \\
\hline G6 & Non treated & 0 & $0 / 5$ & 0 & $0 / 5$ & 0 & $0 / 5$ \\
\hline
\end{tabular}

*Titers expressed as EID 50/ml $\pm \mathrm{SD}$.

The nine flocks under current investigation were allocated at different regions in Sharkia Province during 2018. The examined birds experienced respiratory distresses or a dropin egg production. The present results revealed that the frequently observed clinical signs among examined broiler flocks were respiratory: Sneezing, periorbital swelling with conjunctivitis, nasal and ocular discharges. Swollen kidneys were also noticed. While, the layer flocks showed clinical signs in the form of depression accompanied by a decrease in feed consumption with the drop in egg production ranging from $25 \%$ to $30 \%$ with thin-shelled, rough and misshapen eggs. Comparable clinical signs were recorded among H9N2 infected birds (Naeem et al., 2007; Capua and Terregino, 2009; Qi et al., 2016).

Concerning real time PCR results for determination of the H9N2 subtype as well as other viruses $\mathrm{H} 5, \mathrm{H} 7, \mathrm{NDV}$, and IBV), which revealed only four flocks(broiler/layer) were positive for H9AIV, with no detection of other examined viruses; however, two were positive for IBV, and three flocks were negative.

Detection of H9 subtype AI and IB viruses was reported among chicken congregations suffering from respiratory or egg production problems in natural infections (Sultan et al., 2015a; Abd E1-Hamid et al., 2018).

The HA amino acid identity $\%$ among our isolates shows a percent (97.2\%). While, other Egyptian isolates (20122019) in the gene bank was (94-98.6, and 95.6-98.8\%, respectively). Our detected viruses and the other Egyptian viruses were closely related to two Israeli viruses with high identity\% (94.9-96.7\%). These results were consistent with that of (Adel et al., 2017), who stated that the identity with the Israeli viruses was 95-97\%.
On the other hand, The NA identity \% among our isolates shows (97.9\%), also with other Egyptian isolates in gene bank (2012-2016) shows the percent of (94.5-97.6 and $94.8-97.4 \%$, respectively) and, were closely related to the Israeli viruses with high identity\% (96.4-96.9\%). Similar results were obtained by (Kandeil et al., 2014) who reported the homology of the NA gene among H9N2 isolates ranged from 94.7 to $99.9 \%$.

By browsing the range of identity among amino acids in both HA and NA genes either between our isolates or with the previously isolated viruses in Egypt showed high similarity with minor changes along with the history of isolation from 2011 (Abdel-Latif et al., 2020). Upon the results mentioned above related to molecular identity of H9N2 viruses, the chance of commercial vaccine success to minimize the risk of the virus infection. However, the biological behavior of the virus and the vaccine in experimental birds will be an added value to support this conclusion (Talat et al., 2020).

Phylogenetic analysis revealed that the HA and NA of our Egyptian H9N2 isolates are related to the Middle East H9N2 isolates and maintained a direct out-group of the G1-like viruses, forming a distinct cluster. The same result was obtained by (Kandeil et al., 2017; Abdel-Latif et al., 2020).

The samples were isolated and propagated in the SPF embryonated chicken eggs. Then, the collected allantoic fluids were tested by HA assay to detect the virus titers that produce titers ranging from 27 to 29 . The isolate (A/ chicken/Egypt/S6/2018) revealed 10 9.5/ $100 \mu \mathrm{L} \mathrm{EID}_{50}$ (Reed and Muench, 1938). 
The protection efficacy of commercial H9N2 vaccines was evaluated by two field available vaccines (vaccine $1 \mathrm{~A} /$ chicken/Egypt/ME543V/2016 and vaccine 2(A/chicken/ Iran/Av1221/1998) SPF chicks at $7^{\text {th }}$ day of age and challenged three weeks later.

Table 7: Serological response by ELISA ID-screen H9 kit in experimental chickens.

\begin{tabular}{|c|c|c|c|c|c|}
\hline \multirow{2}{*}{$\begin{array}{l}\text { Group } \\
\text { name }\end{array}$} & \multirow{2}{*}{$\begin{array}{l}\text { Age/ } \\
\text { days }\end{array}$} & \multicolumn{4}{|c|}{ ELISA results* } \\
\hline & & Mean** & $\begin{array}{l}\text { Std. } \\
\text { Deviation }\end{array}$ & $\begin{array}{l}\text { Std. } \\
\text { Error }\end{array}$ & $\begin{array}{l}\text { Per- } \\
\text { centage }\end{array}$ \\
\hline G1 & \multirow[t]{3}{*}{ Day1 } & $1.40^{\mathrm{C}}$ & 0.70 & 0.22 & 0 \\
\hline G2 & & $1.40^{\mathrm{C}}$ & 0.70 & 0.22 & 0 \\
\hline G3 & & $1.10^{\mathrm{C}}$ & 0.32 & 0.10 & 0 \\
\hline G1 & \multirow{3}{*}{$\begin{array}{l}\text { Day7 } \\
\text { Vaccina- } \\
\text { tion day }\end{array}$} & $1.10^{\mathrm{C}}$ & 0.32 & 0.10 & 0 \\
\hline G2 & & $1.30^{\mathrm{C}}$ & 0.48 & 0.15 & 0 \\
\hline G3 & & $1.50^{\mathrm{C}}$ & 0.71 & 0.22 & 0 \\
\hline G1 & \multirow{3}{*}{$\begin{array}{l}\text { Day14 } \\
1^{\text {st }} \text { week } \\
\text { PV }\end{array}$} & $1.50^{\mathrm{C}}$ & 1.58 & 0.50 & 0 \\
\hline G2 & & $6.50^{c}$ & 12.89 & 4.07 & 0 \\
\hline G3 & & $1.10^{c}$ & 0.32 & 0.10 & 0 \\
\hline G1 & \multirow{3}{*}{$\begin{array}{l}\text { Day21 } \\
2^{\text {nd }} \text { week } \\
\text { PV }\end{array}$} & $1051.50^{\mathrm{b}}$ & 1075.19 & 340.01 & $50 \%$ \\
\hline G2 & & $1470.00^{\mathrm{b}}$ & 1194.18 & 377.63 & $80 \%$ \\
\hline G3 & & $4.40^{c}$ & 6.31 & 2.00 & 0 \\
\hline G1 & \multirow{3}{*}{$\begin{array}{l}\text { Day28 } \\
3^{\text {rd }} \text { week } \\
\text { PV }\end{array}$} & $3736.20^{\mathrm{a}}$ & 51.34 & 16.23 & $100 \%$ \\
\hline $\mathrm{G} 2$ & & $3184.40^{\mathrm{a}}$ & 857.87 & 271.28 & $100 \%$ \\
\hline G3 & & $2.00^{c}$ & 0.67 & 0.21 & 0 \\
\hline G1 & \multirow{6}{*}{$\begin{array}{l}\text { Day } 35 \\
7 \text { days } \\
\text { PC }\end{array}$} & $3787.40^{\mathrm{a}}$ & 111.60 & 49.91 & $100 \%$ \\
\hline G2 & & $3533.80^{\mathrm{a}}$ & 366.89 & 164.08 & $100 \%$ \\
\hline G3 & & $3765.40^{\mathrm{a}}$ & 82.54 & 36.91 & $100 \%$ \\
\hline G4 & & $3825.40^{a}$ & 88.21 & 39.45 & $100 \%$ \\
\hline G5 & & $2321.40^{\mathrm{b}}$ & 1439.31 & 643.68 & $100 \%$ \\
\hline G6 & & $1.10^{c}$ & 0.32 & 0.10 & 0 \\
\hline G1 & \multirow{6}{*}{$\begin{array}{l}\text { Day } 42 \\
2^{\text {nd }} \text { week } \\
\text { PC }\end{array}$} & $3906.20^{a}$ & 122.80 & 54.92 & $100 \%$ \\
\hline G2 & & $3812.40^{\mathrm{a}}$ & 22.35 & 9.99 & $100 \%$ \\
\hline G3 & & $4847.40^{\mathrm{a}}$ & 3448.01 & 1542.00 & $100 \%$ \\
\hline G4 & & $4097.00^{a}$ & 2020.47 & 903.58 & $100 \%$ \\
\hline G5 & & $2642.20^{b}$ & 1293.93 & 578.66 & $100 \%$ \\
\hline G6 & & $2.00^{c}$ & 0.67 & 0.21 & 0 \\
\hline
\end{tabular}

Wells of ELISA plate is coated with recombinant H9 hemagglutinin *; ** Anova one way used to test Significance difference between group, the same letters mean nonSignificance difference, significant difference at $\mathrm{p}$ value $(\mathrm{p} \leq$ $0.05) ; \mathrm{PV}=$ post vaccination, $\mathrm{PC}=$ Post challenge. $\mathrm{G} 1$ : vaccine 1 non challenged, G2: vaccine 2 non challenged, G3: vaccine 1 challenged, G4: vaccine 2 challenged, G5: challenged non vaccinated (Pos control), and G6: non treated (Neg control).

Our findings indicated that only some depression and diarrhea were apparent in G5 only and these results were consistent with the previous report of H9 AIV infectious in an experimental situation (Bijanzad et al., 2013; Elfeil et al., 2018), who stated that single H9N2 experimental infection couldn't introduce significant clinical signs. There was no any mortality in all groups during the experiment, which confirmed the low pathogenic nature of H9N2 AIV. This agreed with reported with (Elfeil et al., 2018). In contrast, one study revealed $20 \%$ cumulative mortality in experimentally infected chickens with LPAI H9N2 infection (Abd El-Hamid et al., 2016). Thus, variation in the severity of the symptoms and mortalities could be due to the mentioned experiment done in commercial broiler chickens.

Since one of the most critical challenges among H9N2 vaccination is preventing field virus shedding to avoid wild reassortment, the quantitative shedding was carried in the current study.

Consequently, the vaccine must reduce the virus shedding compared with the group that has challenge virus only (G5 positive control group). It has been shown that H9N2 vaccine one stopped shedding of the field virus at the $3^{\text {rd }}$-day post-challenge and vaccine two succeeded in preventing any field virus shedding completely. Our results are in agreement with the recommendation of (OIE, 2019). Moreover, the results of the H9N2 AIV shedding pattern revealed that there is demarked reduction in virus shedding in tracheal shedding in the 7th DPI in the positive control group. These results agreed with (Khalil et al., 2015).

Regarding serological monitoring, the present study indicated that there is the proper amount of antibodies against $\mathrm{H} 9 \mathrm{~N} 2$ after single vaccination with oil emulsion inactivated vaccine with both vaccines, which support the earlier findings (Lee et al., 2011; Sultan et al., 2015b; Ibrahim and Seioudy, 2020) who mentioned that although a single administration of oil-based inactivated H9N2 LPAI vaccine is very immunogenic and highly protective in laboratory trials using SPF chickens.

Both HI and ELISA were comparable in antibody evaluation. But variation in antibody titers post-challenge may be attributed either to the HA antigen or coated antigen identity with vaccinal and field viruses. In turn, the interpretation of serological results the aforementioned factors should be given to evaluate vaccines. Upon the current serological findings, the threshold of antibody $2^{4}$ in HI and 1800 in ELISA could be protective, particularly against field virus challenge.

Histopathological findings of our study pointed that the H9N2 AIV is epitheliotropic, especially toward respiratory, lymphoid organs, and urinary; the results were obtained (Elfeil et al., 2018). 
The trachea showed mild desquamation of the epithelial cells in infected non-vaccinated G5 and less desquamation in vaccinated challenge $\mathrm{G} 3$ and normal tracheal tissues in the other groups at the $5^{\text {th }}$ day post challenge. These results were close to the results of (Awadin et al., 2018).

The examination of the pulmonary tissue revealed normal pulmonary tissues; however, G5 showed interstitial pneumonia similar finding reported by (Subtain et al., 2011). Contradictories about pulmonary lesions were recorded by (Slemons et al.,1991), who stated no pulmonary lesions. Mild or less significant lung lesions were reported by (Hablolvarid et al., 2004). These variations could be referred to either the experimental birds were commercial or SPF and the strain of challenge virus.

The renal tissue revealed marked interstitial inflammatory cells infiltrations in G5, while moderate local interstitial inflammatory cells infiltrations in G3 and normal renal glomerular and tubular tissues in other groups. These results were close to the results of (El Miniawy et al., 2014), who reported renal lesions in the infected group with Egyptian isolate of LPAI H9N2 in the form of tubule-interstitial nephritis.

In the present study, the predominantly histologic changes in the bursa of Fabricius and cecal tonsils were necrotic some lymphoid follicles. Moreover, congested blood vessels with thickening of septae were seen in the thymus.

These pathological changes in the immune organs could indicate of the involvement of the immune system as well as the immunosuppressive effect of H9N2 subtype on chickens in Egypt. Our results were similar to the lesions observed in the thymus and bursa of Fabricius in chickens inoculated with $10^{6}$ EID50 intra-nasally per bird of H9N2 avian influenza (Hadipour et al., 2011; Abd E1-Hamid et al., 2016). As well as atrophy in the bursa was reported after the inoculation of H9N2 in broiler chickens (Qiang and Youxiang, 2011).

\section{CONCLUSIONS AND RECOMMENDATIONS}

It could be concluded from the presented study that The LPAI H9N2 virus is still circulating in Sharkia Province among both broiler and layer flocks. Under the current experimental circumstances, the H9N2 AIV did not cause severe disease as a single pathogen in SPF chickens and is still low pathogenic. However, concurrent viral and bacterial infections can exacerbate the disease condition. The available commercial vaccines can limit the spread of the field H9N2 virus based on virus shedding.

\section{ACKNOWLEDGMENTS}

This research was supported by grant \#27667 from the Newton Mosharafa, "Improving Vaccines and Diagnostics for Avian influenza Viruses." The authors would also appreciate the STDF, Egypt and Dr Amal AM Eid, professor of Avian and Rabbit Diseases and PI of the project.

\section{NOVELTY STATEMENT}

The available commercial vaccines in Egypt can limit the spread of the field H9N2 virus based on virus shedding.

\section{AUTHOR'S CONTRIBUTION}

Hossam A. Gado conducted the experimental procedures, collected samples and wrote the manuscript. Ibrahim A. Ghanem contributed to design the experimental work, provided guidance, technical support. Abdullah A. Selim helped supervise the molecular studies and participated in sequence analysis. Reem A.Soliman performed the Experimental sample preparations for laboratory analysis. Mounir M. Elsafty supervised the Experimental work and analysis the data. Amal A.M. Eid planned the work, conducted the statistical analyses and critically revised the manuscript.

\section{CONFLICT OF INTEREST}

The authors have declared no conflict of interest.

\section{REFERENCES}

-Abdel-Hamid HS, Ellakany HF, El-Bestawy AR, Gado A (2018). Molecular characterization of H9N2 avian influenza viruses isolated from commercial broiler chickens in Egypt during 2014-2015. Alex. J. Vet. Sci., 56(2): 54-61. https:// doi.org/10.5455/ajvs.220473

-Abdel-Hamid HS, Ellakany HF, Hussien HA, El-bestawy AR, Abdel baky KM (2016). Pathogenicity of an Avian Influenza H9N2 Virus isolated From Broiler Chickens in Egypt. Alex. J. Vet. Sci., 51(2): 90-100. https://doi.org/10.5455/ ajvs. 236275

-Abdel-Latif SA, Atef A, Abdel-aleem AMA, Dahshan AM, Ali A (2020). Characterization of avian influenza H9N2 and Newcastle disease virus isolated from vaccinated chickens in upper Egypt. J. Vet. Med. Res., 27(1). https:// doi.org/10.21608/jvmr.2020.25519.1007

-Adel A, Arafa AS, Hussien HA, EL Sanousi AA (2016). Antibody response of commercial vaccinated layers against H9N2 viruses in Egypt. Glob. Vet., 16(6): 557-564.

-Adel A, Arafa AS, Hussien HA, El-Sanousi AA (2017). Molecular and antigenic traits on hemagglutinin gene of avian influenza H9N2 viruses: Evidence of a new escape mutant in Egypt adapted in quails. Res. Vet. Sci., 112(2017): 132-140. https://doi.org/10.1016/j.rvsc.2017.02.003

-Awadin W, Said H, Abdin S, El-sawak AA (2018). Pathological 
and molecular studies on avian influenza virus (H9N2) in broilers. Asian J. Anim. Vet. Adv., 13(3): 232-244. https:// doi.org/10.3923/ajava.2018.232.244

-Bano S, Naeem K, Malik SA (2003). Evaluation of pathogenic potential of Avian Influenza virus serotype H9N2 in chickens. Avian Dis., 47: 817-822. https://doi.org/10.1637/00052086-47.s3.817

-Ben Shabat M, Meir R, Haddas R, Lapin E, Shkoda I, Raibstein I, Perk S, Davidson I (2010). Development of a real-time TaqMan RT-PCR assay for the detection of H9N2 avian influenza viruses. J. Virol. Methods, 168: 72-77. https://doi. org/10.1016/j.jviromet.2010.04.019

- Bijanzad P, Momayez R, Fard BHM, Hablolvarid HM, Mahmoodzadeh M, Moghaddam JRA, Kaboli K, Azizpour A, Fatemeh E (2013). Study on clinical aspects of SPF chickens infected with H9N2 subtype of Avian Influenza virus. Ann. Biol. Res., 4(3): 81-85.

- Callison SA, Ribet SM, Sun S, Ikuta N, Hilt D, Leiting V, Kleven SH, Suarez DL, Garcia M (2006). Development and validation of Real-Time Taqmqn polymerase chain reaction assay for the detection of Mycoplasma gallisepticum in Naturally infected birds. Avian Dis., 50: 537-544. https:// doi.org/10.1637/7639-050106R.1

- Capua I, Alexander DJ (2008). Avian influenza vaccines and vaccination in birds. Vaccine, 26: 70-73. https://doi. org/10.1016/j.vaccine.2008.07.044

- Capua I, Terregino C (2009). Clinical traits and pathology of avian influenza infections, guidelines for farm visit and differential diagnosis in avian influenza and newcastle disease. Capaua, Ilaria and Alexander, D.J. eds springerVerlag Italia pp. 45-72. https://doi.org/10.1007/978-88470-0826-7_6

-Elfeil WK, Abouelmatti RR, Mandour MF, Diab MS, Rady $M$ (2018). Experimental infection of chickens by avian influenza $\mathrm{h} 9 \mathrm{n} 2$ virus: monitoring of tissue tropism and pathogenicity. J. Egypt. Vet. Med. Assoc., 78(3): 369-383.

-El-Miniawy HF, Kawkab AA, EL-Sanousi AA, Marwa MSK (2014). Effect of aflatoxin induced immunosuppression on pathogenesis of H9N2 avian influenza virus. Pak. Vet. J., 34(2): 234-238.

-El-Nagar A, Ibrahim A (2007). Case study of the Egyptian poultry sector. World J. Poult. Sci., 61(3): 491-514.

-El-Zoghby EF, Arafa AS, Hassan MK, Aly MM, Selim A, Kilany WH, Selim U, Nasef S, Aggor MG, Abdelwahab EM, Hafez HM (2012). Isolation of H9N2 avian influenza virus from bobwhite quail (Colinusvirginianus) in Egypt. Arch. Virol., 157: 1167-1172. https://doi.org/10.1007/ s00705-012-1269-z

- Hablolvarid MH, Haghdost IS, Pourbakhsh SA, Gholami MR (2004). Histopathological study of intratracheally inoculated A/Chicken/Iran/259/1998 (H9N2) influenza virus in chicken. Arch. Razi Inst., 58: 51-62.

- Hadipour HH, Farjadin SH, Azad F, Kamarvan M, Deghan A (2011). Nephropathogenctiy of H9N2 Avian influenza virus in commercial broiler chickens following intratracheal inoculation. J. Anim. Vet. Adv., 10(13): 1706-1710. https:// doi.org/10.3923/javaa.2011.1706.1710

-Hagag NM, Erfan AM, El-Husseiny M, Shalaby AG, Saif MA, Tawakol MM, Nour AA, Selim AA, Arafa AS, Hassan MK, Hassan WMM, Fahmy HA, Ibraheem E, Attia M, Abdelhakim AMM, Shahein MA, Naguib MM (2019). Isolation of a novel reassortant highly pathogenic avian influenza (H5N2) virus in Egypt. Viruses J., 11(6): 565. https://doi.org/10.3390/v11060565

- Hegazy AME-S, Hassan AFI, Tolba HMN (2019). Cocirculation of major avian respiratory viruses in Egypt: avian influenza and Newcastle disease viruses. Adv. Anim. Vet. Sci., 7(s2): 96-106.

-Ibrahim HH, Seioudy M (2020). Comparison of the efficacy of local and imported inactivated combined H9-ND virus vaccines in protection of broiler flocks against H9N2 infection in Egypt. Benha Vet. Med. J., 83: 52-56. https:// doi.org/10.21608/bvmj.2020.23632.1163

-Kandeil A, El-Shesheny R, Maatouq A, Moatasim Y, Cai Z, Mckenzie P, Webby R, Kayali G, Ali MA (2017). Novel reassortant $\mathrm{H} 9 \mathrm{~N} 2$ viruses in pigeons and evidence for antigenic diversity of $\mathrm{H} 9 \mathrm{~N} 2$ viruses isolated from quails in Egypt. J. Gen. Virol., 98: 548-562. https://doi.org/10.1099/ jgv.0.000657

-Kandeil A, El-Shesheny R, Maatouq A, Moatasim Y, Shehata MM, Bagato O (2014). Genetic and antigenic evolution of H9N2 avian influenza viruses circulating in Egypt between 2011 and 2013. Arch. Virol., 159: 2861-2876. https://doi. org/10.1007/s00705-014-2118-z

-Khalil A,Hussein HA, Tolba S, El-sanousi A (2015).Preparation and evaluation of $\mathrm{H} 9 \mathrm{~N} 2$ vaccine adjuvated with montanide ISA71 VG. Glob. Vet., 14(5): 670-674.

-Kumar S, Stecher G, Tamura K (2016). MEGA7: Molecular Evolutionary Genetics Analysis version 7.0 for bigger datasets. Mol. Biol. Evol., 33: 1870-1874. https://doi. org/10.1093/molbev/msw054

-Lee D, Kwon JS, Lee HJ, Lee YN, Hur W, Hong YH, Lee JB, Park SY, Choi IS, Song CS (2011). Inactivated H9N2 avian influenza virus vaccine with gel-primed and mineral oil boosted regimen could produce improved immune response in broiler breeders. Poult. Sci., 90: 1020-1022. https://doi. org/10.3382/ps.2010-01258

-Löndt BZ, Nunez N, Banks J, Nili H, Johnson LK, Alexander DJ (2008). Pathogenesis of highly pathogenic avian influenza A/turkey/Turkey/1/2005 H5N1 in Pekin ducks (Anasplatyrhynchos) infected experimentally. Avian Pathol., 37(6): 619-627. https://doi. org/10.1080/03079450802499126

-Luczo JM, Stambas J, Durr PA, Michalski WP, Bingham J (2015). Molecular pathogenesis of H5 highly pathogenic avian influenza: The role of the haemagglutinin cleavage site motif. Rev. Med. Virol., 25(6): 406-430. https://doi. org/10.1002/rmv.1846

- Meir R,Maharat O,FarnushiY,Simanov L (2010).Development of a real-time TaqMan ${ }^{\circledR}$ RT-PCR assay for the detection of infectious bronchitis virus in chickens, and comparison of RT-PCR and virus isolation. J. Virol. Methods, 163: 190194. https://doi.org/10.1016/j.jviromet.2009.09.014

- Naeem K, Siddique N, Ayaz M, Jalalee MA (2007). Avian influenza in Pakistan: outbreaks of low- and highpathogenicity avian influenza in Pakistan during 20032006. Avian Dis., 51(1 Suppl.): 189-193. https://doi. org/10.1637/7617-042506R.1

- Naeem K, Ullah A, Manvell RJ, Alexander DJ (1999). Avian influenza A subtype H9N2 in poultry in Pakistan. Vet. Record, 145: 560. https://doi.org/10.1136/vr.145.19.560

- OIE (2019). World organisation for animal health. Chapter 2.3.4. Avian influenza. In: Manual of diagnostic tests and vaccines for terrestrial animals. Paris (France): OIE [accessed on 24 March 2019]. http://www.oie.int/en/internationalstandard-setting/terrestrial-manual/. 
- OIE Manual (2015). Manual of diagnostic tests and vaccines for terrestrial animals-avian influenza. In OIE Terrestrial Manua, OIE: Rome, Italy.

-Qi X, Tan D, Wu C, Tang C, Li T, Han X, Wang J, Liu C, Li R, Wang J (2016). Deterioration of eggshell quality in laying hens experimentally infected with $\mathrm{H} 9 \mathrm{~N} 2$ avian influenza virus. Vet. Res., 47: 35. https://doi.org/10.1186/s13567016-0322-4

-Qiang F, Youxiang D (2011). The effects of H9N2 influenza a on the immune system of broiler chickens in the Shandong Province. Transbound. Emerg. Dis., 58: 145-151. https:// doi.org/10.1111/j.1865-1682.2010.01192.x

- Reed LJ, Muench H (1938). A simple method of estimating fifty per cent endpoints. Am. J. Epidemiol., 27: 493-497. https://doi.org/10.1093/oxfordjournals.aje.a118408

-Shehata AA, Sedeik ME, Elbestawy AR, Zain EL-Abideen MA, Ibrahim HH, Kilany WH, Ali A (2019). Co-infections, genetic, and antigenic relatedness of avian influenza $\mathrm{H} 5 \mathrm{~N} 8$ and $\mathrm{H} 5 \mathrm{~N} 1$ viruses in domestic and wild birds in Egypt. Poult. Sci., 98: 2371-2379. https://doi.org/10.3382/ps/ pez011

- Slemons RD, Condobery PK, Swayne DE (1991). Assessing pathogenicity potential of waterfowl-origin type a influenza viruses in chickens. Avian Dis., 35(1): 210-215. https://doi. org/10.2307/1591316

-Slomka MJ, Coward VJ,Banks J,Londt BZ,Brown IH, Voermans J, Koch G, Handberg KJ, Jorgensen PH, Cherbonnel-Pansart $M$ (2007). Identification of sensitive and specific avian influenza polymerase chain reaction methods through blind ring trials organized in the European Union. Avian Dis., 51: 227-234. https://doi.org/10.1637/7674-063006R1.1

- Slomka MJ, Pavlidis T, Coward VJ, Voermans J, Koch G, Hanna A, Banks AJ, Brown IH (2009). Validated RealTime reverse transcriptase PCR methods for the diagnosis and pathotyping of Eurasian $\mathrm{H} 7$ avian influenza viruses. Influenza Respir. Viruses, 3: 151-164. https://doi. org/10.1111/j.1750-2659.2009.00083.x
- Sprygin AV, Andreychuk DB, Kolotilov AN, Volkov MS, Runina IA, Mudrak NS, Borisov AV, Irza VN, Drygin VV, Perevozchikova NA (2010). Development of a duplex realtime TaqMan PCR assay with an internal control for the detection of Mycoplasma gallisepticum and Mycoplasma synoviae in clinical samples from commercial and backyard poultry. Avian Pathol., 39(2): 99-109. https://doi. org/10.1080/03079451003604621

- Subtain, MU, Chaudhry ZI, Anjum AA, Maqbool A, Sadique U (2011). Study on pathogenesis of low pathogenic avian influenza virus H9 in broiler chickens. Pak. J. Zool., 43(5): 999-1008.

- Sultan H, Abdel-razik AG, Shehata AA, Ibrahim M, Talaat S (2015a). Characterization of infectious bronchitis viruses circulating in Egyptian chickens during 2012 and 2013. J. Vet. Sci. Med. Diagn., 4: 5.

-Sultan HA, Abd el-razik AG, Allam TS, El-deeb HA (2015b). Inactivated oil emulsion $\mathrm{H} 9 \mathrm{~N} 2$ vaccine in broiler chickens: Pathogenesis and clinicopathological studies. Am. J. Res. Commun., 3(5): 38-53.

- Suvarna KS, Layton C, John BD (2018). Bancroft's theory and practice of histological techniques. $8^{\text {th }}$ Edition.

-Swayne DE, Glisson, JR (2013). Diseases of poultry; Wiley-Blackwell: Ames, Iowa. https://doi. org/10.1002/9781119421481

- Talat S, Abouelmaatti RR, Almeer R, Abdel-daim MM, Elfeil WK (2020). Comparison of the effectiveness of two different vaccination regimes for avian influenza H9N2 in broiler chicken. Animals, 10: 1875. https://doi.org/10.3390/ ani10101875

-Wise MG, Suarez DL, Seal BS, Pedersen JC, Senne DA, King DJ, Kapczynski DR, Spackman E (2004). Development of a real-time reverse-transcription PCR for detection of Newcastle disease virus RNA in clinical samples. J. Clin. Microbiol., 42: 329-338. https://doi.org/10.1128/ JCM.42.1.329-338.2004

Supplementary Table S1: Descriptive data of examined chicken flocks that suspected to be infected with avian influenza virus subtype $\mathrm{H} 9$.

\begin{tabular}{|c|c|c|c|c|c|c|c|c|c|}
\hline $\begin{array}{l}\text { Flock } \\
\text { No }\end{array}$ & locality & $\begin{array}{l}\text { H9N2 AI virus } \\
\text { vaccination* }\end{array}$ & $\begin{array}{l}\text { Date of ex- } \\
\text { amination }\end{array}$ & Breed & $\begin{array}{l}\text { Age } \\
\text { (Day) }\end{array}$ & $\begin{array}{l}\text { Flock } \\
\text { capacity }\end{array}$ & $\begin{array}{l}\text { No of exam- } \\
\text { ined birds }\end{array}$ & $\begin{array}{l}\text { No of collect- } \\
\text { ed swabs }\end{array}$ & $\begin{array}{l}\text { Lab } \\
\text { code }\end{array}$ \\
\hline 1 & Menia-ElKamh & 70 and 112 day & $28 / 11 / 2018$ & Decalb & 245 & 5000 & $\mathrm{Nd}$ & $5 \mathrm{~T}+5 \mathrm{C}$ & S1 \\
\hline 2 & Menia-ElKamh & 15,45 and 120 day & $1 / 12 / 2018$ & Bovans & 305 & 3750 & $\mathrm{Nd}$ & $5 \mathrm{~T}+5 \mathrm{C}$ & S2 \\
\hline 3 & Menia-ElKamh & 5 day & $10 / 12 / 2018$ & Ross & 23 & 7000 & 3 & $5 \mathrm{~T}+5 \mathrm{C}$ & S3 \\
\hline 4 & Meet Abo Ali & No & $12 / 12 / 2018$ & Balady & 52 & 6500 & 3 & $5 \mathrm{~T}+5 \mathrm{C}$ & S4 \\
\hline 5 & Menia-ElKamh & No & $16 / 12 / 2018$ & Balady & 85 & 2000 & 3 & $5 \mathrm{~T}+5 \mathrm{C}$ & S5 \\
\hline 6 & Menia-ElKamh & No & $18 / 12 / 2018$ & Cobb & 28 & 3500 & 3 & $5 \mathrm{~T}+5 \mathrm{C}$ & S6 \\
\hline 7 & Menia-ElKamh & No & $24 / 12 / 2018$ & Balady & 300 & 5000 & 3 & $5 \mathrm{~T}+5 \mathrm{C}$ & S7 \\
\hline 8 & Tal Rak & 35 and 109 day & $28 / 12 / 2018$ & $\mathrm{H} \& \mathrm{~N}$ & 365 & 2000 & 3 & $\mathrm{Nd}$ & S8 \\
\hline 9 & Menia-ElKamh & No & $30 / 12 / 2018$ & Cobb & 18 & 700 & 3 & $5 \mathrm{~T}+5 \mathrm{C}$ & S9 \\
\hline
\end{tabular}

$\mathrm{Nd}$, not done * routine vaccination against NDV, IBV, IBD and AIV subtype H5 were given to these flocks. 